\title{
Detection of coagulase gene in Staphylococcus aureus from several dairy farms in East Java, Indonesia, by polymerase chain reaction
}

\author{
Mustofa Helmi Effendi' ${ }^{1}$ Mirza Atikah Madarina Hisyam ${ }^{1}$, Poedji Hastutiek² and Wiwiek Tyasningsih ${ }^{3}$
}

1. Department of Veterinary Public Health, Faculty of Veterinary Medicine, Airlangga University, Surabaya, Indonesia

2. Department of Veterinary Parasitology, Faculty of Veterinary Medicine, Airlangga University, Surabaya, Indonesia;

3. Department of Veterinary Microbiology, Faculty of Veterinary Medicine, Airlangga University, Surabaya, Indonesia. Corresponding author: Mustofa Helmi Effendi, e-mail: mheffendi@yahoo.com

Co-authors: MAMH: madarinahisyam@gmail.com,PH: poedjihastutiek@gmail.com, WT: witya_kh@yahoo.com

Received: 11-09-2018, Accepted: 19-11-2018, Published online: 10-01-2019

doi: 10.14202/vetworld.2019.68-71 How to cite this article: Effendi MH, Hisyam MAM, Hastutiek P, Tyasningsih W (2019) Detection of coagulase gene in Staphylococcus aureus from several dairy farms in East Java, Indonesia, by polymerase chain reaction, Veterinary World, 12(1): 68-71.

\begin{abstract}
Aim: This study was conducted to study the coagulase (coa) gene-based genetic diversity of Staphylococcus aureus, isolated from different samples of cattle from three different regions in East Java Province, Indonesia.

Materials and Methods: A total of 160 raw milk samples collected in East Java Province, Indonesia, were screened for the presence of $S$. aureus. The presumptive isolates were confirmed by coa test. The confirmed $S$. aureus isolates were subjected to coa gene polymerase chain reaction.
\end{abstract}

Results: Of 160 different samples, 20 (12.5\%) isolates of $S$. aureus were confirmed by positive coa test. Of $20 \mathrm{~S}$. aureus isolates, 19 (95\%) isolates carried coa gene. Six different genotypes of coa gene, i.e., $440 \mathrm{bp}, 510 \mathrm{bp}, 547 \mathrm{bp}, 680 \mathrm{bp}$, $740 \mathrm{bp}$, and $820 \mathrm{bp}$ were obtained. One coa genotypes, $510 \mathrm{bp}$ (10 isolates) were observed in polymorphism to be more prevalent than the others, and the genotype was present in at least one isolates from every region.

Conclusion: It can be concluded that coa gene is easily epidemiological tool for detection of variation strain from $S$. aureus.

Keywords: coagulase gene, coagulase test, polymorphism, raw milk, Staphylococcus aureus.

\section{Introduction}

Staphylococcus aureus is the most pathogenic bacteria species of the genus Staphylococcus [1]. $S$. aureus can be isolated from domestic and food animals and associated with disease such as mastitis [2]. $S$. aureus secretes two clotting factors, coagulase (coa) protein and von Willebrand factor binding protein [3]. coa protein is an important phenotypic determinant and virulence factor of $S$. aureus [4]. The ability of its coa to clot plasma is a defining property of $S$. aureus and distinguished the species from other coa-negative staphylococci [5].

Variable genome structure that is associated with strains variant in the certain area shown by $S$. aureus was known to be responsible for the emergence of different epidemiological profiles [6]. Staphylocoagulase, as the major phenotypic determinant of $S$. aureus, exists in various allelic forms caused by the genetic variance in its 3'-end coding region [7]. The variations in its 3 ' region have resulted in the gene to have polymorphic properties which, therefore, the same analysis result in all strains would not be possible [8].

\footnotetext{
Copyright: Effendi, et al. Open Access. This article is distributed under the terms of the Creative Commons Attribution 4.0 International License (http://creativecommons.org/licenses/by/4.0/), which permits unrestricted use, distribution, and reproduction in any medium, provided you give appropriate credit to the original author(s) and the source, provide a link to the Creative Commons license, and indicate if changes were made. The Creative Commons Public Domain Dedication waiver (http://creativecommons.org/ publicdomain/zero/1.0/) applies to the data made available in this article, unless otherwise stated.
}

The distinguishing factor of $S$. aureus coa gene lies in the heterogeneity of the region containing multiple repeated strands with 81 bp length in the 3' region of the gene. Each $S$. aureus strains have differences in replication number and gene restriction location [9]. Polymerase chain reaction (PCR) amplification results of this region showed different size and number of DNA bands which can be differentiated further using enzyme restriction [7]. The unique property of staphylocoagulase which can be easily analyzed using a simple technique such as PCR amplification and the availability of this enzyme in all strains of $S$. aureus made coa gene amplification to be the simplest molecular typing method in $S$. aureus epidemiological study. Using this epidemiological method, coa gene typing is considered a simple and effective method for typing $S$. aureus isolates from bovine mastitic milk [10]. Epidemiological studies based on analysis of the coa gene have shown that $S$. aureus isolates could be divided into a number of subtypes, but only a few are responsible for most cases of bovine mastitis in different geographical areas [11].

In Indonesia, especially in East Java, little is known about the genotypic variance and the distribution of $S$. aureus isolated from raw cow's milk. Therefore, the aim of this study was to detect the genotype variance of $S$. aureus isolated from raw cow's milk sample in three regions in East Java based on its coa gene by PCR amplification and to understand the strains distribution. 


\section{Materials and Methods}

\section{Ethical approval}

Raw milk were used in this study, hence ethical approval was not necessary. Raw milk samples were collected from three regions in East Java province, Indonesia.

\section{Bacterial isolates}

A total of $20 \mathrm{~S}$. aureus isolates from raw milk obtained from several farms in three regions such as Pasuruan region for Nongkojajar and Grati farm, Malang region for Batu farm, and Lumajang region for Senduro farm in East Java, Indonesia, were used in this study that shown in Table-1. The isolation and identification were performed for counting bacteria using conventional phenotyping method involved mannitol salt phenol red agar growth (E. Merck, Darmstadt, Germany), Gram staining, microscopic observation, catalase test, and tube coa test [12].

\section{DNA preparation}

All $S$. aureus isolates were subcultured on MSA and incubated at $37^{\circ} \mathrm{C}$ for $24 \mathrm{~h}$ before DNA extraction. The DNA of all $S$. aureus isolates in this study was extracted using QIAamp ${ }^{\circledR}$ DNA Mini Kit (QIAGEN, Singapore) and done using the manufacturer method.

\section{PCR amplification of the coa gene}

For PCR amplification, a total of $50 \mu 1$ reaction mixture contained $28 \mu \mathrm{l}$ Go taq green master mix (Promega, Germany), $20 \mu \mathrm{l}$ RNase free water, and $1 \mu \mathrm{l}$ of each forward and reverse primer was prepared. The primer used for coa gene amplification as described by Hookey et al. [13] was 5'ATA GAG ATG CTG GTA CAG G3' and 5'GCT TCC GAT TGT TCG ATG C3'. A total of $2.5 \mu 1$ of DNA template were added to the mixture. The mixture then amplified using PCR cycler according to the protocol of Akineden et al. [14] with modification as following: Predenaturation at $94^{\circ} \mathrm{C}$ for $45 \mathrm{~s}$, followed by 30 cycles of denaturation at $94^{\circ} \mathrm{C}$ for $1 \mathrm{~min}$, annealing at $58^{\circ} \mathrm{C}$ for $1 \mathrm{~min}$, and extension at $72^{\circ} \mathrm{C}$ for $1 \mathrm{~min}$. The amplification ended by a final extension at $72^{\circ} \mathrm{C}$ for $2 \mathrm{~min}$. The presence of PCR products was determined by electrophoresis of $10 \mu \mathrm{l}$ of products in $2 \%$ agarose gel with TBE buffer and 100 bp DNA ladder as a marker (Promega, Germany).

\section{Results}

The $19 S$. aureus isolates produced a single band with variance molecular size ranging from $440 \mathrm{bp}$ to 820 bp (Figure-1). One isolate in this study did not produce the band. The $20 \%$ of isolates accounted for 4 of 20 produced a single band of $440 \mathrm{bp}$ length. A single band with a molecular size of $510 \mathrm{bp}$ was produced by most (50\%) of the isolates. A single band with $547 \mathrm{bp}$, $680 \mathrm{bp}$, and $820 \mathrm{bp}$ length was produced by one (5\%) isolate, respectively. The $10 \%(2 / 20)$ isolates produced single band with molecular size $740 \mathrm{bp}$. According to the size of the product, the $S$. aureus isolates in this study can be grouped into 7 groups (Table-2).
Table-1: Number of raw milk samples and Staphylococcus aureus from several dairy farms.

\begin{tabular}{lcc}
\hline Name of farm & $\begin{array}{c}\text { Number of } \\
\text { samples }\end{array}$ & $\begin{array}{c}\text { Positive } \\
\text { Staphylococcus aureus }\end{array}$ \\
\hline Nongkojajar (P) & 32 & 9 \\
Grati (G) & 43 & 4 \\
Batu (B) & 49 & 3 \\
Senduro (S) & 36 & 4 \\
Total & 160 & 20 \\
\hline
\end{tabular}

Table-2: Group of isolates based on coa gene amplification product size.

\begin{tabular}{lccc}
\hline Groups & $\begin{array}{c}\text { Molecular } \\
\text { size (bp) }\end{array}$ & $\begin{array}{c}\text { Number of } \\
\text { isolates }\end{array}$ & Percentage \\
\hline Group A & 440 & $4 / 20$ & 20 \\
Group B & 510 & $10 / 20$ & 50 \\
Group C & 547 & $1 / 20$ & 5 \\
Group D & 680 & $1 / 20$ & 5 \\
Group E & 740 & $2 / 20$ & 10 \\
Group F & 820 & $1 / 20$ & 5 \\
Group G & No band & $1 / 20$ & 5 \\
\hline
\end{tabular}

coa=Coagulase

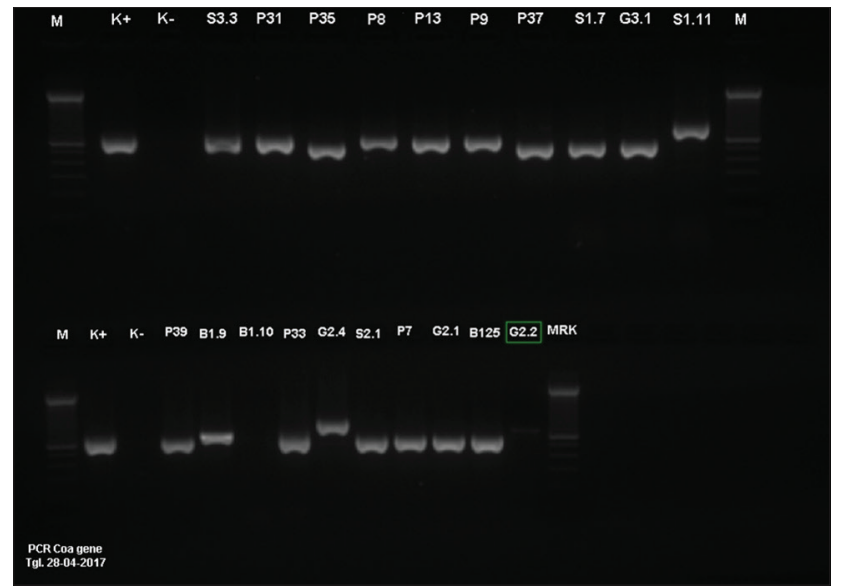

Figure-1: Agarose gel electrophoresis of Staphylococcus aureus polymerase chain reaction products. Lane $\mathrm{M}=1$ : $100 \mathrm{bp}$ molecular weight standard, $\mathrm{K}+=$ Control positive, $\mathrm{K}$-=Control negative, Senduro farm (S), Nongkojajar farm (P), Batu farm (B), Grati farm (G).

\section{Discussion}

In this study, $20 \mathrm{~S}$. aureus strains were subtyped by coa gene PCR and resulted in single amplicon which indicates no size polymorphisms [15]. Amplification of coa gene showed six different PCR products of $440,510,547,680,740$, and $820 \mathrm{bp}$. The difference of amplification products reflects the variation in coa gene length among $S$. aureus strains. Former studies were done by other researchers [13-20] using the same primer pairs and also showed that different coa gene types exist. The reason behind this polymorphism is unclear, but it is likely caused by the insertion, or deletion mutations of some portions in 3' end region of coa gene resulted in a change of the gene size and probably also the antigenic properties of the enzyme. This region of the gene may have an important role in 
antigenic variation and its defense some inhibitory mechanism of anti-coa agents [18].

The coa gene PCR amplification of 20 S. aureus isolates revealed 6 coa PCR types. The most prevalence $(50 \%)$ coa gene type was 510 bp length which found in at least one isolate of $S$. aureus from every location. Studies $[16,18,21,22]$ from different countries showed that various coa types can be found in $S$. aureus isolates from milk samples and some of the genotypes were more prevalent. In a previous study [8], it was reported that predominant types of $S$. aureus could be varied in different areas and they may be more resistant to neutrophil bactericidal activities than that of the rare types, which indicates that they may have different features that help them to survive host immunity mechanism.

Several coa gene types (547 bp, $680 \mathrm{bp}$, and $820 \mathrm{bp}$ ) were infrequent and only found in a particular location and not present in another location. The infrequent genotypes might be less adapted to the mammary gland therefore easily eliminated from the herd and less easily spread [18]. These different and exclusiveness found among the location may be caused by the pathogen coevolution against its host. The pressure of environments, management, animal trading specific to a certain geographic area would lead to the selection of distinct and genetically adaptable strains [8].

The presence of coa genotypes that differ by geographic location and the genotypes that prevailed in each location could be explained by the pathogens-hosts coevolution and the differences in management, nutrition, locations, reservoir bacteria, and environment. The phenomenon of strain homogeneity among some heads in different region also might be explained by the animal trading among regions, the transmission of the strains among herds with close geographic location, the range of discriminatory power of the typing method used, and hosts adaptation to $S$. aureus strains that is present in the environment [18]. The finding of the same genotype among distant location farm could be explained by the interregional herd movement; pathogen spread with human as a carrier, or the homoplasy phenomenon that is the independent acquisition of similar structures without commons ancestors [23].

One isolates analyzed in this study found to produce no amplification products. The isolate showed positive results in coa test tube and based on other identification test results phenotypically identified as $S$. aureus. This contradiction results between traditional and molecular method also reported in a former study [24] where 10 strains that classified as coa negative by coa test tube were found to be positive by a molecular method using PCR. The findings emphasize the use of molecular methods in the identification and detection of $S$. aureus $[24,25]$.

The PCR amplification results of $S$. aureus isolated from cow milk from several herds in East Java,
Indonesia, showed the genotype variance of $S$. aureus based on its coa gene polymorphism properties. The results also revealed that the coa gene types of $S$. aureus strains circulated among herds in the area were varied by 7 types. Among those types, one genotype $(510 \mathrm{bp}$ ) was predominant, and three genotypes (547 bp, $680 \mathrm{bp}$, and $820 \mathrm{bp}$ ) were unique to particular herds and infrequent. These research results of coa gene amplification by PCR are very useful and relatively simple method for $S$. aureus genotyping, and further studies using RFLP technique and sequencing methods on large strains collection from various sources could provide a complete picture of a characteristic of $S$. aureus circulated in the area as well as the epidemiology pattern.

\section{Conclusion}

This study has shown that based on its coa gene polymorphism the strains of $S$. aureus that contaminated milk from several dairy farms in three locations in East Java consists of at least 6 types with one genotype predominant strain. It can be concluded that coa gene is easily epidemiological tool for detection of variation strain from $S$. aureus. Further researches using RFLP technique and sequencing method on various origin strains might be necessary to understand the epidemiology profile of contamination and infection.

\section{Authors' Contributions}

MHE is a supervised and project leader. MAMH is a data analysis and collected samples and PH carried out molecular analysis. WT carried out bacterial isolation. All authors contributed in the drafting and revision of the manuscript. All authors read and approved the final manuscript.

\section{Acknowledgments}

The authors would like to thank the Ministry of Research, Technology and Higher Education of Indonesia for providing research funds with grant numbers; $893 / \mathrm{UN} 3 / 2017$ on the research title: PENANGGULANGAN ANTIBIOTICS RESISTANT BERSUMBER PANGAN ASAL HEWAN (PAH) MELALUI DETEKSI DINI DENGAN POLYMERASE CHAIN REACTION. This article is part of the research.

\section{Competing Interests}

The authors declare that they have no competing interests.

\section{Publisher's Note}

Veterinary World remains neutral with regard to jurisdictional claims in published institutional affiliation.

\section{References}

1. Foster, T.J. (2011) Pathogens in milk Staphylococcus aureus-molecular. Reference module in food science. In: 
Encyclopedia of Dairy Science. $2^{\text {nd }}$ ed. Academic Press, Oxford. p104-110.

2. Martin, E., Lina, G. and Dumitrescu, O. (2014) Staphylococcus. Staphylococcus aureus. In: Batt, C.A. and Tortorello, M.L., editors. Encyclopedia of Food Microbiology. $2^{\text {nd }}$ ed., Vol. 3. Elsevier, London, Burlington, San Diego. p501-507.

3. Gharib, A.A., Attia, M.A.A. and Bendary, M.M. (2013) Detection of the coa gene in Staphylococcus aureus from different sources by polymerase chain reaction. Int. J. Microbiol. Res., 4(1): 37-42.

4. Abbas, B.A., Khudor, M.H. and Hanoon, B.M. (2014) Isolation and identification of Staphylococcus aureus from bovine and the detection of its coagulase gene (coa) using polymerase chain reaction (PCR). Sci. Res. Essays, 9(20): 864-868.

5. Foster, T.J. and Geoghegan, J.A. (2015) Chapter 37: Staphylococcus aureus. In: Tang, Y.W., Sussman, M., Liu, D., Poxton, I. and Schwartzman, J., editors. Molecular Medical Microbiology. $2^{\text {nd }}$ ed. Academic Press, Boston. p655-674.

6. Abdulghany, H.M. and Khairy, R.M. (2014) The frequency of Methicillin-resistant Staphylococcus aureus and coagulase gene polymorphism in Egypt. Int. J. Bacteriol., 2014: 1-6.

7. Goh, S.H., Byrne, S.K., Zhang, J.L. and Chow, A.W. (1992) Molecular typing of Staphylococcus aureus on the basis of coagulase gene polymorphisms. J. Clin. Microbiol., 30(7): 1642-1645.

8. Sanjiv, K., Kataria, A.K., Sharma, R. and Singh, G. (2008) Epidemiological typing of Staphylococcus aureus by DNA restriction fragment length polymorphism of coa gene. Vet. Arh., 78(1): 31-38.

9. Omar, N.Y., Ali, H.A.S., Harfoush, R.E.H. and El Khayat, E.H. (2014) Molecular typing of Methicillin resistant Staphylococcus aureus clinical isolates on the basis of protein a dan coagulase gene polymorphisms. Int. J. Microbiol., 2014: 1-11.

10. Aslantafi, O., Demr, C., Turutolu, H., Cantekn, Z., Ergun, Y. and Doruer, G. (2007) Coagulase gene polymorphism of Staphylococcus aureus isolated from subclinical bovine mastitis. Turk. J. Vet. Anim. Sci., 31(4): 253-257.

11. Javid, F., Taku, A., Bhat, M.A., Badroo, G.A., Mudasir, M. and Sofi, T.A. (2018) Molecular typing of Staphylococcus aureus based on coagulase gene. Vet. World, 11(4): 423-430.

12. Effendi, M.H. and Harijani, N. (2017) Cases of Methicillinresistant Staphylococcus aureus (MRSA) from raw milk in East Java, Indonesia. Glob. Vet., 19(1): 500-503.

13. Hookey, J.V., Richardson, J.F. and Cookson, B.D. (1998) Molecular typing of Staphylococcus aureus based on PCR restriction fragment length polymorphism and DNA sequence analysis of the coagulase gene. J. Clin. Microbiol., 36(4): 1083-1089.

14. Akineden, O., Annemüller, C., Hasan, A.A., Lämmler, C., Wolter, W. and Zschöck, M. (2001) Toxin genes and other characteristics of Staphylococcus aureus isolates from milk of cows with mastitis. Clin. Diagn. Lab. Immunol., 8(5): 959-964.

15. Salasia, S.I.O., Khusnan, Z., Lämmler, C. and Zschöck, M. (2004) Comparative studies on pheno-and genotypic properties of Staphylococcus aureus isolated from bovine subclinical mastitis in central Java in Indonesia and Hesse in Germany. J. Vet. Sci., 5(2): 103-109.

16. Katsuda, K., Hata, E., Kobayashi, H., Kohmoto, M., Kawashima, K., Tsunemitsu, H. and Eguchi, M. (2005) Molecular typing of Staphylococcus aureus isolated from bovine mastitic milk on the basis of toxin genes and coagulase gene polymorphisms. Vet. Microbiol., 105(3-4): 301-305.

17. Fournier, C., Kuhnert, P., Frey, J., Miserez, R., Kirchhofer, M., Kaufmann, T., Steiner, A. and Graber, H.U. (2008) Bovine Staphylococcus aureus: Association of virulence genes, genotypes, and clinical outcome. Res. Vet. Sci., 85(3): 439-448.

18. Saei, D.H., Ahmadi, M., Mardani, K. and Batavani, R.A. (2009) Molecular typing of Staphylococcus aureus isolated from bovine mastitis based on polymorphism of the coagulase gene in the North West of Iran. Vet. Microbiol., 137(1-2): 202-206.

19. Hata, E., Katsuda, K., Kobayashi, H., Uchida, I., Tanaka, K. and Eguchi, M. (2010) Genetic variation among Staphylococcus aureus strains from bovine milk and their relevance to methicillin-resistant isolates from humans. $J$. Clin. Microbiol., 48(6): 2130-2139.

20. Salasia, S.I.O., Tato, S., Sugiyono, N., Ariyanti, D. and Prabawati, F. (2011) Genotypic characterization of Staphylococcus aureus isolated from bovines, humans, and food in Indonesia. J. Vet. Sci., 12(4): 353-361.

21. Guler, L., Ok, U., Gunduz, K., Guicu, Y. and Hadimli, H.H. (2005) Antimicrobial susceptibility and coagulase gene typing of Staphylococcus aureus isolated from bovine clinical mastitis cases in Turkey. J. Dairy Sci., 88(9): 3149-3154.

22. da Silva, E.R., Boechat, J.U.D. and da Silva, N. (2005) Coagulase gene polymorphism of Staphylococcus aureus isolated from goat mastitis in Brazilian dairy herds. Lett. Appl. Microbiol., 42(1): 30-34.

23. Jagielski, T., Puacz, E., Lisowski, A., Siedlecki, P., Dudziak, W., Międzobrodzki, J. and Krukowski, H. (2014) Short communication: Antimicrobial susceptibility profiling and genotyping Staphylococcus aureus isolates from bovine mastitis in Poland. J. Dairy Sci., 97(10): 6122-6128.

24. Hamza, D.A., Dorgham, S.M. and Arafa, A. (2015) Coagulase gene typing with emphasis on Methicillinresistance Staphylococci: Emergence to public health. $A d v$. Infect. Dis., 5: 196-203.

25. Elsayed, M.S., El-Bagoury, A.M. and Dawoud, M.A. (2015) Phenotypic and genotypic detection of virulence factors of Staphylococcus aureus isolated from clinical and subclinical mastitis in cattle and water buffaloes from different farms of Sadat city in Egypt. Vet. World, 8(9): 1051-1058. 